\title{
Evaluation of Oral Administration of Pirfenidone in Preventing Epidural Fibrosis Formation in Rats
}

\author{
Siçanlarda Epidural Fibroz Oluşumunu Önlemede Oral Pirfenidon \\ Uygulamasının Değerlendirilmesi
}

(1D Zahir Kızılay ${ }^{1}$, (1) Nesibe Kahraman Çetin², (1) Özge Çevik³, (1) Serdar Aktaş4, (1) Hakan Öztürk5

${ }^{1}$ Aydın Adnan Menderes University Faculty of Medicine, Department of Neurosurgery, Aydın, Turkey

${ }^{2}$ Aydın Adnan Menderes University Faculty of Medicine, Department of Pathology, Aydın, Turkey

${ }^{3}$ Aydın Adnan Menderes University Faculty of Medicine, Department of Biochemistry, Aydın, Turkey

4Aydın Adnan Menderes University, Faculty of Veterinary Medicine, Department of Pharmacology and Toxicology, Aydın, Turkey

${ }^{5}$ Aydın Adnan Menderes University Faculty of Medicine, Department of Clinical Biostatistics, Aydın, Turkey

\section{Keywords}

Laminectomy, fibroblast growth factor, transforming growth factor, pirfenidone, epidural fibrosis

Anahtar Kelimeler

Laminektomi, fibroblast büyüme faktörü, dönüştürücü büyüme faktörü, pirfenidone, epidural fibrozis

Received/Geliş Tarihi : 16.06.2021

Accepted/Kabul Tarihi : 16.12.2021

doi:10.4274/meandros.galenos.2021.60234

Address for Correspondence/Yazışma Adresi: Assoc. Prof. Zahir Kızılay,

Aydın Adnan Menderes University Faculty of Medicine, Department of Neurosurgery, Aydın, Turkey

Phone : +902564441256

E-mail : zahir.kizilay@adu.edu.tr

ORCID ID: orcid.org/0000-0002-2021-0406

(C) Meandros Medical and Dental Journal, Published by Galenos Publishing House.

This is article distributed under the terms of the Creative Commons Attribution NonCommercial 4.0

International Licence (CC BY-NC 4.0).

\begin{abstract}
Objective: To investigate the oral administration of pirfenidone on eperidural fibrosis formation (EF).

Materials and Methods: Twenty four rats were divided into three equal groups. Group 1 (control), group 2 ( $25 \mathrm{mg} / \mathrm{kg}$ pirfenidone), and group $3(50 \mathrm{mg} / \mathrm{kg})$. Thoracic laminectomies were performed in all rats. Pirfenidone was given orally once a day for 30 days. Vertebral column samples were removed surgically at the end of the procedure. EF grading, number of fibroblasts and arachnoidal involvoment were evaluated. TGF- $\beta 1$ and basic fibroblast growth factor (bFGF) were analyzed using quantitative real-time polymerase chain reaction, and synthesized proteins were examined.

Results: In group 3, EF formation was less than the other groups. The factors in the emergence of antifibrotic activity at $50 \mathrm{mg} / \mathrm{kg}$ doses were investigated, and it was revealed that pirfenidone reduced fibroblast proliferation, and showed this effect by reducing TGF- $\beta 1$ and bFGF expression in fibrotic tissue.

Conclusions: Pirfenidone can be a potential agent for EF treatment.

Öz

Amaç: Bu çalışmanın amacı pirfenidonun oral yoldan uygulanmasının eperidural fibroz (EF) oluşumu üzerindeki etkisini araştırmaktır.

Gereç ve Yöntemler: Yirmi dört sıçan üç eşit gruba ayrıldı: grup 1 (kontrol), grup 2 (25 mg/kg oral pirfenidon) ve grup 3 (50 mg/kg oral pirfenidon). Tüm sıçanlara torakal laminektomi yapıldı. Pirfenidon 30 gün boyunca günde bir kez ağızdan verildi. İşlemin sonunda vertebral kolon örnekleri cerrahi olarak alındı. EF derecesi, fibroblast sayısı ve araknoidal tutulum histopatolojik olarak değerlendirildi. Transforming büyüme faktörü- $\beta 1$ (TGF- $\beta 1$ ) ve bazik fibroblast büyüme faktörünün (bFGF) gen ekspresyonu, kontitatif gerçek zamanlı polimeraz zincir reaksiyonu kullanılarak analiz edildi ve sentezlenen proteinler incelendi.

Bulgular: Grup 3'te EF oluşumu diğer gruplardan azdı. Elli mg/kg dozlarında antifibrotik aktivitenin ortaya çıkmasında rol oynayan faktörler araştııılığında pirfenidonun fibroblast proliferasyonunu azalttığı ve bu etkiyi TGF- $\beta 1$ ve bFGF ekspresyonunu azaltarak gösterdiği ortaya konmuştur.

Sonuç: Pirfenidon, EF tedavisinde potansiyel bir ajan olabilir.
\end{abstract}




\section{Introduction}

Laminectomy is commonly performed to treat the spine pathologies (1). Depending on the dimensions of a laminectomy, removal of the soft tissues from the epidural space can cause many complications. Epidural fibrosis (EF) is one such common complication (2). This EF tissue can also be described as a healing tissue; however, this healing tissue increases in the epidural space after laminectomy, and may cause adhesion between tissues, and compression around neural tissue $(3,4)$. These excessive healing tissue can also lead to the reappearance of the patient's existing symptoms before surgery $(5,6)$. Therefore, reducing adhesion via $E F$ is critical for reducing the success rate of surgery.

In the literature, many agents have been used (18). However, no effective treatment has been reported (2). Additional surgical interventions for the treatment of EF may also lead to many complications $(5,7-9)$. Additionally, many surgical interventions after the first surgery can also cause more fibrotic tissue than was formed in the first operation (8). Therefore, the preventing the formation of EF is the best approach (9).

EF formation is occurs as a result of an inflammatory process (10). This complex inflammation process ends with a process in which cellularity decreases but the extracellular matrix component accumulates excessively $(7,10)$. Basic fibroblast growth factor (bFGF) and transforming growth factor beta (TGF- $\beta$ ) have been showed to have a critical role in the formation of fibrosis $(7,10,11)$. Therefore, researchers have focused on altering fibroblast proliferation and trans differentiation.

Pirfenidone, which is known as 5-methyl-Nphenyl-2-(1H)-pyridone, is an antifibrotic medicine (11-13). It has been approved for the treatment of idiopathic pulmonary fibrosis (11-14). According to previous studies, pirfenidone reduced the deposition of collagen and inflammatory cells, and inhibited the proliferation and differentiation fibroblasts by TGF- $\beta 1$ (14). Therefore, pirfenidone, which has antifibrotic properties, can also be a potential agent for reducing EF formation.

Here we performed an experimental laminectomy in rats to show the effect of the pirfenidone on EF formation.

\section{Materials and Methods}

\section{Animals}

The experimental procedure was reviewed and approved by the animal Ethics Committee of Aydın Adnan Menderes University Animal Experiments Local Ethics Committee (approval no: 64583101/2019/017, date: 26.03 .2019$)$.). Twenty-four female Wistar albino rats, the average weight of which was $350 \pm 10 \mathrm{mg}$, were used in this study. Environmental conditions of the experimental study were $20-24{ }^{\circ} \mathrm{C}, 50 \pm 10 \%$ humidity and a 12-hour light/dark cycle. The subjects were ensured easy access to food and water.

\section{Experimental groups}

Group 1: Laminectomy; only $\mathrm{T} 11$ and $\mathrm{T} 12$ laminectomies were performed $(n=8)$.

Group 2: Twenty-five $\mathrm{mg} / \mathrm{kg}$ pirfenidone; T11 and T12 laminectomies and after hemostasis, surgical layers were closed in accordance with the normal anatomic layer. Then $25 \mathrm{mg} / \mathrm{kg}$ pirfenidone was given orally once a day for 30 days $(n=8)$.

Group 3: Fifty $\mathrm{mg} / \mathrm{kg}$ pirfenidone; the same procedure as group 2 was performed, and then 50 $\mathrm{mg} / \mathrm{kg}$ pirfenidone was given orally once a day for 30 days $(n=8)$.

\section{Anesthesia and Surgical Procedure}

A mixture of ketamine $(50 \mathrm{mg} / \mathrm{kg}$, Ketasol, Richter Pharma, Austria) and xylazine (10 mg/kg, Bioveta Plc, Czech Republic) was given intraperitoneally to the subjects in the groups for anesthesia. They were set up in the prone position. The laminectomy areas of the rat were wetted for shaving and then povidone-iodine was applied. After a longitudinal midline incision, the T11-T12 laminae were exposed and laminectomies were performed at the same levels. After hemostasis, the surgical wound was closed in accordance with anatomic layers. Cervical dislocation was performed under deep anesthesia for sacrifice at the end of the postoperative $30^{\text {th }}$ day. Then, the vertebral column was removed en bloc.

\section{Histopathologic Evaluation}

After appropriate samples were taken from the materials, they were placed in cassettes, and routine tissue follow-up was performed in an automatic tissue tracking device within 14-16 hours. Serial sections, 3-4 $\mu \mathrm{m}$ in size were taken from the samples embedded in paraffin blocks. The slides were stained with Masson's 
Trichrome Hematoxylin-Eosin (H\&E), and then they were analyzed with a microscope.

The extent of fibrous tissue and its relationship with dura mater were scored according to He schame (15). The arachnoid involvement was also noted.

The cell density of scar tissue observed in the EF area was evaluated according to the Hinton method (16). The density of Vimentin were evaluated during the immunohistochemical examination.

Immunohistochemistry of Vimentin

Immunohistochemical staining was performed with a DAKO brand automatic staining device using an Avidin-Biotin complex system. Evaluations for vimentin immunohistochemical staining were performed under the light microscopy at x40, x100, x200, and x400 magnifications. If the staining rate was $10 \%$ or more, the staining was accepted as positive. The degree of staining was evaluated according to the staining rates that can be observed at different magnifications. The staining visible at $\times 200$ magnification was considered light, the stainingvisible at $\times 100$ magnification was considered medium, and the staining visible at $x 40$ magnification was considered strong staining.

\section{Western Blot Analysis for Proteins}

Protein analysis was performed using the western blot analysis method previously defined by Arabacı Tamer et al. (17). The blotted membrane was blocked with 3\% Bovine serum albumin for two hours at room temperature. The membrane was incubated with primary antibody (1:500 dilution monoclonal antibody anti-TGF- $\beta$, anti-FGF, anti-Bactin, Santa Cruz Biotechnology, Heidelberg, Germany) for 24 hours at a temparture of $4{ }^{\circ} \mathrm{C}$ temperature. Afterwards, the membrane was washed twice in TBST (Tris-buffered saline containing $0.1 \%$ Tween-20) and membrane was incubated with secondary antibody (1:2000 antimouse IgG1-HRP and anti-rabbit IgG-HRP Santa Cruz Biotechnology) for two hours at room temperature. Band analysis was performed using $\mathrm{NIH}$-ImageJ software. For normalization, $\beta$-actin was used with respect to each band.

\section{Quantitative Real-time Polymerase Chain Reaction (qRT-PCR) Analysis}

The quantitative real-time PCR (qPCR) analysis method was used for gene analysis (18). The primers used were as follows: GAPDH Forward 5'-ATGACTCTACCCACGGCAAG-3', GAPDH Reverse 5'-CTGGAAGATGGTGATGGGTT-3': TGF- $\beta$ Forward
5'-ACCTGCAAGACCATCGACATG-3', TGF- $\beta$-Reverse 5'-CGAGCCTTAGTTTGGACAGGAT-3', FGF Forward 5'-AAGCCCGTCGGTGTCCATGG-3', FGF Reverse 5'-GATGGCACAGTGGATGGGAC-3'. It was made using Applied Biosystem Software for the analysis. Relative quantitative data were calculated by the $2-{ }^{\Delta \Delta} \mathrm{Ct}$ method. The calculation of gene expression ratios was expressed with GAPDH as a reference gene.

\section{Statistical Analysis}

Whether the quantitative variables were normally distributed among the groups was checked using the Kolmogorov-Smirnov test. In group comparisons, oneway analysis of variance (ANOVA) and Kruskal-Wallis $\mathrm{H}$ test was used. Pairwise comparisons of groups were made using the Tukey HSD and Bonferroni corrected multiple comparison test for ANOVA and KruskalWallis $\mathrm{H}$ test, respectively. Descriptive statistics were expressed as mean \pm standard deviation for variables with normal distribution and median $\left(25^{\text {th }}-75^{\text {th }}\right.$ percentile) for variables without normal distribution. $\mathrm{P}<0.05$ value was evaluated as statistically significant.

\section{Results}

Effect of Pirfenidone on Epidural Fibrosis in Histopathological Analysis

When the groups were evaluated in according to $\mathrm{EF}$, the grade 3 (Figure $1 \mathrm{~A}$ and $1 \mathrm{~B}$ ) $\mathrm{EF}$ were dominant in group 1, grade 2 (Figure $1 C$ and $1 D$ ) and grade 3 EF were predominant in group 2, and grade 1 (Figure $1 \mathrm{E}$ and $1 \mathrm{~F}$ ) and grade $2 \mathrm{EF}$ were dominant in group 3. According to these results, group 3 showed a statistically significant difference between other groups $(p<0.001)$ (Table 1$)$. In addition to this, arachnoid involvement was detected in three rats in group 1 and two rats in group 2, but in group 3, no arachnoid involvement was detected (Table 2).

Effect of Pirfenidone on Average Fibroblast Numbers in Histopathological Analysis

When groups were compared in terms of fibroblast count, the highest number of fibroblasts was in group 1 , while the least number of fibroblasts was in group 3. The number of fibrolasts in group 2 was found to be between group 1 and group 3 (Table 1). According to these results, a $50 \mathrm{mg} / \mathrm{kg}$ dose of pirfenidone provided a statistically significant in decreasing the fibroblasts number compared to other groups $(p<0.001)$. 


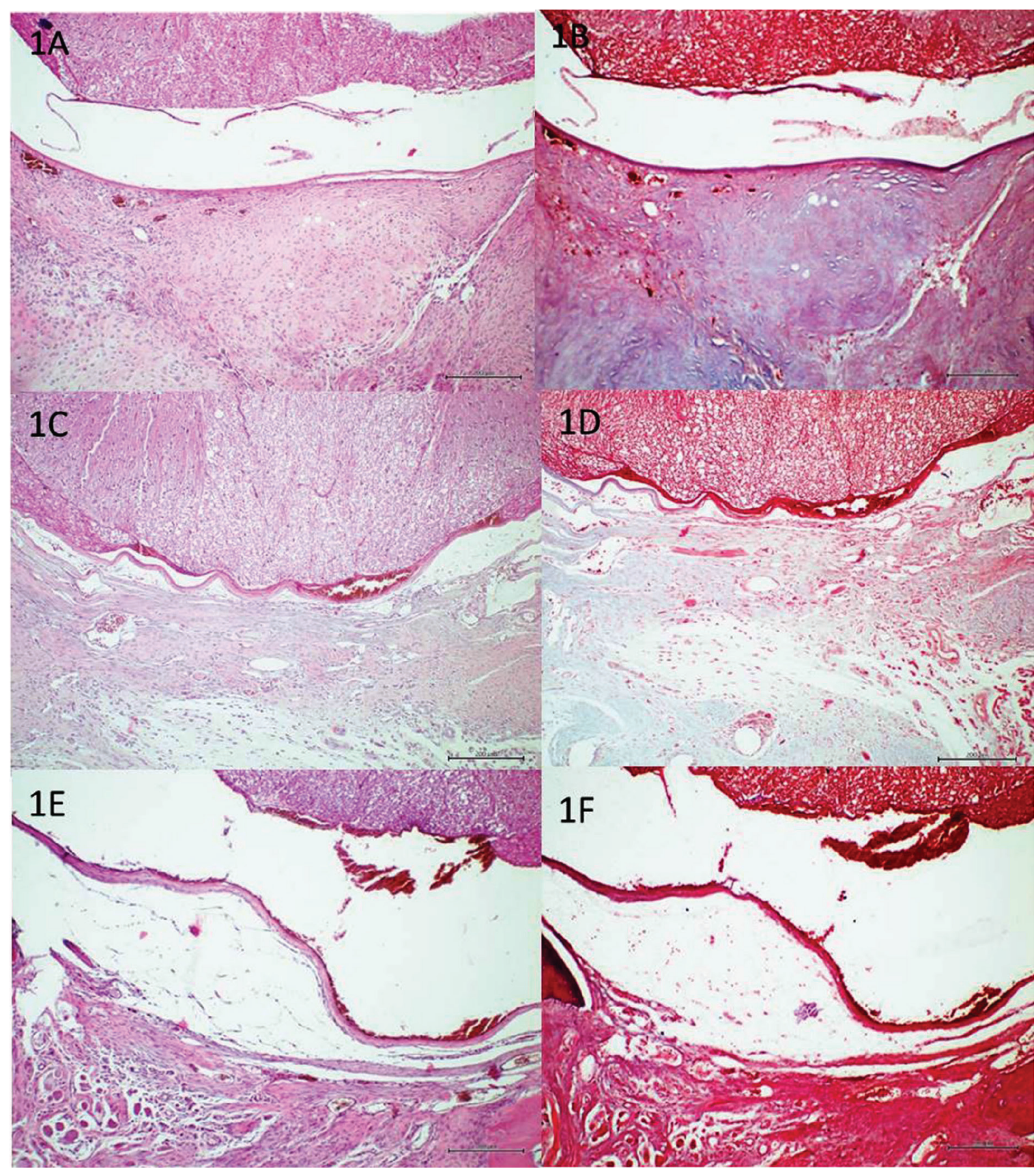

Figure 1. Dense scar tissue adherent to the dura mater was showed in the group 1 [H\&E (1A) and Masson's trichrome (1B) staining, scale bar: $200 \mu \mathrm{m}, \times 100$ magnification]. Moderate scar tissue was observed in the group 2 [H\&E (1C) and Masson's trichrome (1D) staining, scale bar: $200 \mu \mathrm{m}, \mathrm{x} 100$ magnification]. Loose scar tissue without adherence to the dura mater was found in the group 3 [H\&E (1E) and Masson's trichrome (1F) staining, scale bar: $200 \mu \mathrm{m}$, x100 magnification]

Effect of Pirfenidone on Immunostaining in Histopathological Analysis

To compare the results of immunostaining, a comparison was made by scoring 3 for severe staining (Figure 2A), 2 for moderate staining (Figure
$2 \mathrm{~B}$ ), and 1 for low staining (Figure $2 \mathrm{C}$ ). When groups were compared in terms of vimentin staining, it was found that severe staining was dominant in group 1 , and severe and moderate staining was dominant in group 2, whereas in group 3. According to these 
results, there was no statistically significant difference between group 1 and group 2, but there was also a statistically significant difference between group 3 and other groups $(p<0.001)$ (Table 1$)$.

\section{Western Blot Analysis Results}

TGF- $\beta 1$ protein expression levels were decreased with pirfenidone treatment in group 2 and group 3 $(p<0.001)$ compared with group 1 . Moreover, bFGF protein expression levels were suppressed in group
2 and group $3(p<0.001)$. Both protein expression results showed that the treatment of a $50 \mathrm{mg} / \mathrm{kg}$ dose of pirfenidone in laminectomy suppressed bFGF and TGF- $\beta 1$ protein expression levels more (Figure 2D) (Table 3).

\section{qRT-PCR analysis Results}

qRT-PCR results revealed that TGF-B1 gene expression significantly decreased in the pirfenidone treated groups when compared with group 1

Table 1. Comparison of the groups according to the epidural fibrosis grading, fibroblast counting, vimentin immunostaining, and qRT-PCR analysis results. Similar letters in the same line indicate similarity between groups; different letters represent difference between groups

\begin{tabular}{|l|l|l|l|l|} 
& Group 1 (n=8) & Group 2 (n=8) & Group 3 (n=8) & p-value \\
\hline Epidural fibrosis & $3.0(3.0-3.0)^{\mathrm{a}}$ & $2.0(2.0-3.0)^{\mathrm{a}}$ & $1.5(1.0-2.0)^{\mathrm{b}}$ & $<0.001$ \\
\hline Average fibroblast number & $183.5 \pm 11.4^{\mathrm{a}}$ & $153.5 \pm 28.9^{\mathrm{b}}$ & $113.3 \pm 18.8^{\mathrm{c}}$ & $<0.001$ \\
\hline Vimentin immunostaining & $3.0(3.0-3.0)^{\mathrm{a}}$ & $2.5(2.0-3.0)^{\mathrm{a}}$ & $1.5(1.0-2.0)^{\mathrm{b}}$ & $<0.001$ \\
\hline bFGF/GAPDH & $1.279 \pm 0.419^{\mathrm{a}}$ & $0.618 \pm 0.174^{\mathrm{b}}$ & $0.071 \pm 0.049^{\mathrm{c}}$ & $<0.001$ \\
\hline TGF-B1/GAPDH & $1.454 \pm 0.402^{\mathrm{a}}$ & $0.617 \pm 0.156^{\mathrm{b}}$ & $0.111 \pm 0.060^{\mathrm{c}}$ & $<0.001$ \\
\hline
\end{tabular}

Similar letters in the same line indicate similarity between groups, different letters represent difference between groups. qRT-PCR: Quantitative realtime polymerase chain reaction, TGF- $\beta$ : Transforming growth factor beta, bFGF: Basic fibroblast growth factor
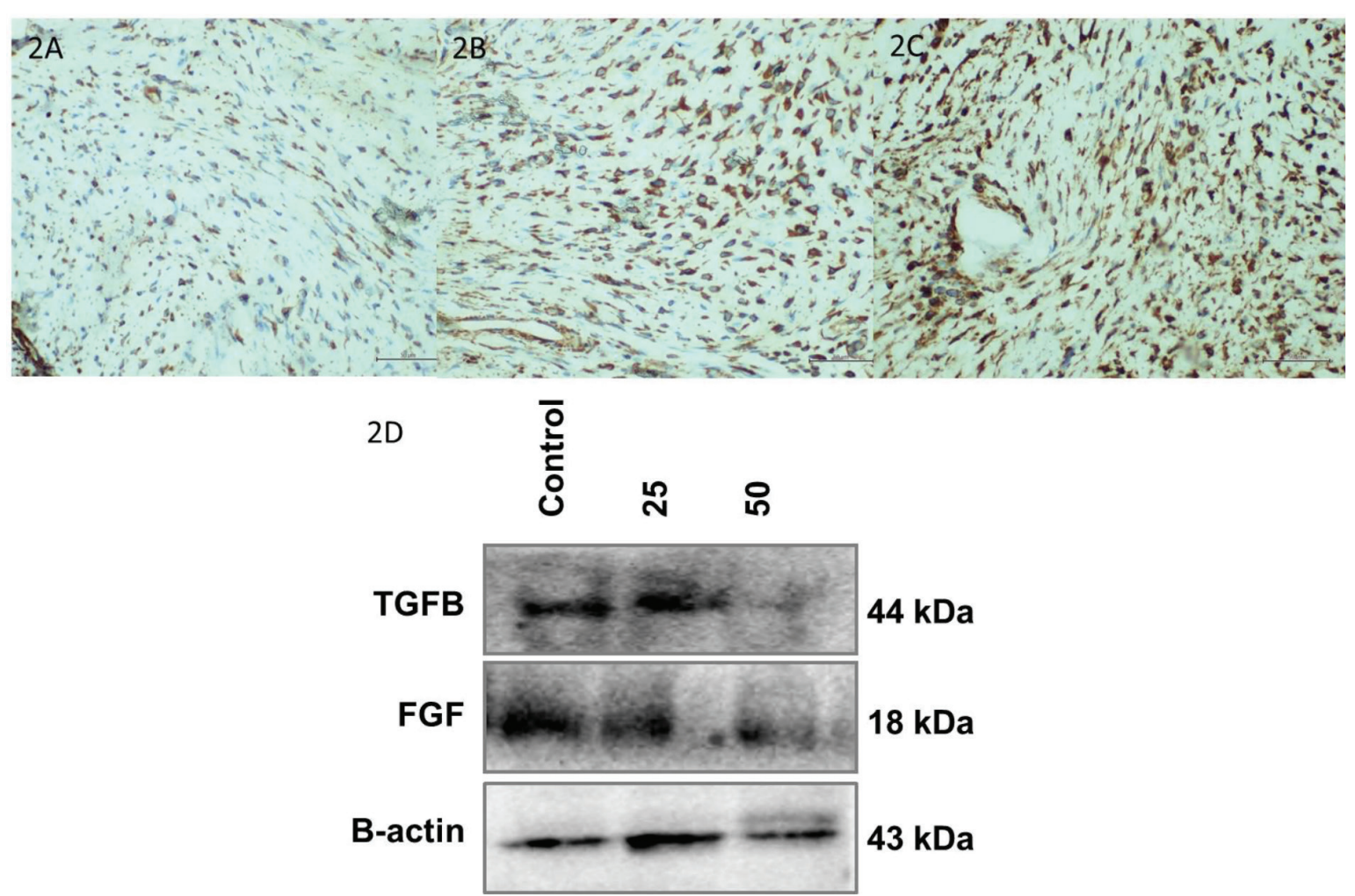

Figure 2. The density of vimentin cells was lowest in the group $3(2 \mathrm{~A})$ and lower in the group 2 (2B) compared with the group 1 (2C). (Scale bar: $50 \mu \mathrm{m}, x 400$ magnification). Comparison of TGF- $\beta 1$ and FGF expression of the groups according to the Western blot analysis results (2D)

FGF: Fibroblast growth factor, TGF- $\beta$ : Transforming growth factor beta 
$(p<0.001)$. bFGF gene expression levels were also significantly decreased in the pirfenidone-treated groups when compared with the group 1 ( $p<0.001$ ). TGF-B1 and bFGF gene expression results showed that administration of a $50 \mathrm{mg} / \mathrm{kg}$ dose of pirfenidone suppressed increasing gene levels in $\mathrm{EF}$, thus showing a better effect (Table 1).

\section{Discussion}

Our study is the first to use pirfenidone at $25 \mathrm{mg} /$ $\mathrm{kg}$ and $50 \mathrm{mg} / \mathrm{kg}$ doses in a laminectomy model and to examine its effect on the EF formation. According to the results of our study, it was revealed that, when pirfenidone was administered orally at 50 $\mathrm{mg} / \mathrm{kg}$ doses, it statistically significantly decreased EF formation compared with controls and $25 \mathrm{mg} / \mathrm{kg}$ doses of pirfenidone. In addition, this study revealed that pirfenidone reduced fibroblast proliferation and showed this effect by reducing TGF- $\beta 1$ and FGF expression in fibrotic tissue.

In addition to decreasing TGF- $\beta$ expression, many factors may be effective in the emergence of this antifibrotic effect of pirfenidone. In previous studies related to $E F$, it was revealed that reducing the effect of factors such as interleukin (IL)-1, IL-6, tumor necrosis factor (TNF)- $\alpha$, platelet-derived growth factor, FGF and vascular endothelial growth factor (VEGF) reduced EF formation $(8,19-21)$. When the studies related with pirfenidone were examined, a study conducted by Oku et al. (11) revealed that pirfenidone decreased lung fibrosis by reducing the interferon (IF) $-\gamma$, bFGF and TGF- $\beta$ expression. In another study conducted by Guo et al. (14) in a silica-induced lung fibrosis model, the

Table 2. Comparison of the groups according to the arachnoid involvement

\begin{tabular}{|l|l|l|l|l|}
\hline \multicolumn{2}{|c|}{} & Group 1 & Group 2 & Group 3 \\
\hline \multirow{2}{*}{ Arachnoid involvement } & - & 5 & 6 & 8 \\
\cline { 2 - 5 } & + & 3 & 2 & 0 \\
\hline
\end{tabular}

authors reported that the use of pirfenidone reduced the expression of IL-1 $\beta$, TNF- $\alpha$ and IL- 6 in lung tissue. In addition to these, in one in vitro study conducted by Liu et al. (22), the authors reported that pirfenidone showed an antifibrotic effect by reducing angiogenesis by decreasing the expression of VEGF/VEGFR2. This reveals that pirfenidone has an active role in reducing EF formation in the proliferation phase, and may also have an effect as an anti-inflammatory agent.

Another possible factor related with the emergence of antifibrotic activity may be that pirfenidone uses different pathways in different tissues. Analyzing pirfenidone from this point of view, Sun et al. (13) reported that pirfenidone showed antifibrotic properties by using the TGF- $\beta 1 / \mathrm{Smad} / \mathrm{CTGF}$ pathway. Liu et al. (23) suggested that pirfenidone could have an antifibrotic effect by antagonizing the MAPK signaling pathway. In another study, Sun et al. (24) reported that pirfenidone showed antifibrotic activity by antagonizing the Smad and PI3K/AKT pathway. In addition to these studies, in a study conducted by Guo et al. (14), the authors reported that pirfenidone showed antifibrotic activity by antagonizing the TGF- $\beta / \mathrm{smad} 2 / 3$ pathways. The fact that pirfenidone has an antifibrotic activity over different pathways reveals that pirfenidone has a pleiotropic feature. Therefore, pirfenidone may also be used in different diseases beyond lung fibrosis, such as EF.

Another factor in the emergence of its antiinflammatory and antifibrotic activity may be due to its dose-related effect. Many studies have revealed the dose-dependent effect of pirfenidone. One of these experimental studies was by Sun et al. (13), who reported that pirfenidone decreased collagen accumulation and fibroblast proliferation both in vivo and in vitro depending on the dose. In another study was by Liu et al. (23), pirfenidone was shown to reduce TGF- $\beta$, type- 3 collagen, $\alpha$-SMA and fibronectin in a dose-dependent manner. In addition, Shi et al.

Table 3. Comparison of protein expression of the groups according to the Western blot analysis results. Similar letters in the same line indicate similarity between groups; different letters represent difference between groups

\begin{tabular}{|l|l|l|l|l|}
\hline & Group 1 & Group 2 & Group 3 & p-value \\
\hline bFGF/B-actin & $1.112 \pm 0.081^{\mathrm{a}}$ & $0.770 \pm 0.076^{\mathrm{b}}$ & $0.374 \pm 0.029^{\mathrm{c}}$ & $<0.001$ \\
\hline TGF- $\beta$ 1/B-actin & $1.100 \pm 0.063^{\mathrm{a}}$ & $0.824 \pm 0.054^{\mathrm{b}}$ & $0.220 \pm 0.062^{\mathrm{c}}$ & $<0.001$ \\
\hline
\end{tabular}

Similar letters in the same line indicate similarity between groups, different letters represent difference between groups, TGF- $\beta$ : Transforming growth factor beta, bFGF: Basic fibroblast growth factor 
(25) revealed that pirfenidone reduced fibroblast proliferation and collagen accumulation in a dosedependent manner. In our study, pirfenidone reduced the EF grade, fibroblast proliferation and TGF- $\beta 1$ and bFGF expression in a dose-dependent manner. The results of our experiment are supported by the literature.

In this study, although we show for the first time that the use of oral pirfenidone has a positive effect on reducing the formation of EF, the study has some limitations. First, only two different doses of pirfenidone were administered. Second, in this initial study, molecular mechanisms were not investigated to reveal the mechanism of action of pirfenidone. Finally, a small sample size was used.

\section{Conclusion}

According to the results of our study, it was revealed that the use of oral pirfenidone decreased EF formation. In the emergence of this effect of pirfenidone, it has been demonstrated that at least two growth factors, namely TGF- $\beta 1$ and bFGF, reduce the level of both gene expression and protein production depending on the dose. Therefore, pirfenidone can be a potential agent for EF.

\section{Ethics}

Ethics Committee Approval: The experimental procedure was reviewed and approved by the animal Ethics Committee of Aydın Adnan Menderes University Animal Experiments Local Ethics Committee (approval no: 64583101/2019/017, date: 26.03.2019).

Informed Consent: Informed consent is not required.

Peer-review: Externally and internally peerreviewed.

\section{Authorship Contributions}

Surgical and Medical Practices: Z.K., N.K.Ç., S.A., Concept: Z.K., S.A., Design: Z.K., Data Collection or Processing: Z.K., Ö.Ç., Analysis or Interpretation: N.K.Ç., Ö.Ç., H.Ö., Literature Search: Z.K., N.K.Ç., Ö.Ç., Writing: Z.K.

Conflict of Interest: No conflict of interest was declared by the authors.

Financial Disclosure: ADUBAP-TPF-19047.

\section{References}

1. Ismailoglu O, Kizilay Z, Cetin NK, Topcu A, Berber O. Effect of curcumin on the formation of epidural fibrosis in an experimental laminectomy model in rats. Turk Neurosurg 2019; 29: 440-4.

2. Albinana-Cunningham JN, Ripalda-Cemborain P, Labiano T, Echeveste JI, Granero-Molto F, Alfonso-Olmos M. Mechanical barriers and transforming growth factor beta inhibitor on epidural fibrosis in a rabbit laminectomy model. J Orthop Surg Res 2018; 13: 72.

3. Guler S, Akcali O, Sen B, Micili SC, Sanli NK, Cankaya D. Effect of plateled-rich plasma, fat pad and dural matrix in preventing epidural fibrosis. Acta Ortop Bras 2020; 28: 31-5.

4. Sun HH, Wang JC, Feng XM, Zhu SL, Cai J. Allicin inhibits proliferation and promotes apoptosis of human epidural scar fibroblast. World Neurosurg 2020; 136: e460-8.

5. Wang S, Li X, Yan L, Nie Q, Dai J, Chen H, et al. Tamoxifen inhibits fibroblast proliferation and prevents epidural fibrosis by regulating the AKT pathway in rats. Biochem Biophys Res Commun 2018; 497: 937-42.

6. Demirel E, Yildiz K, Çadirci K, Aygün H, Şenocak E, Gündoğdu B. Effect of platelet-rich fibrin on epidural fibrosis and comparison to ADCON Gel and hyaluronic acid. Acta Orthop Traumatol Turc 2018; 52: 469-74.

7. Xu H, Li P, Liu M, Liu C, Sun Z, Guo X, et al. CCN2 and CCN5 exerts opposing effect on fibroblast proliferation and transdifferentiation induced by TFG- $\beta$. Clin Exp Pharmacol Physiol 2015; 42: 1207-19.

8. Kizilay Z, Cetin NK, Topcu A, Ismailoglu O, Omurlu IK, Aktas S, et al. Effect of etanercept on the formation of epidural fibrosis in an experimental model. Turk Neurosurg 2018; 28: 111-7.

9. Zhang C, Kong X, Ning G, Liang Z, Qu T, Chen F, et al. All-trans retinoic acid prevents epidural fibrosis through NF-KB signalling pathway in post-laminectomy rats. Neuropharmacology 2014; 79: 275-81.

10. Ozturk Y, Bozkurt I, Yaman ME, Guvenc Y, Tolunay T, Bayram P, et al. Histopathologic analysis of tamoxifen on epidural fibrosis. World Neurosurg 2018; 111: e941-8.

11. Oku H, Shimizu T, Kawabata T, Nagira M, Hikita I, Ueyama A, et al. Antifibrotic action of pirfenidone and prednisolone: different effects on pulmonary cytokines and growth factors in bleomycininduced murine pulmonary fibrosis. Eur J Pharmacol 2008; 590 : 400-8.

12. Stahnke T, Kowtharapu BS, Stachs $O$, Schmitz KP, Wurm J, Wree $A$, et al. Suppression of TFG- $\beta$ pathway by pirfenidone decreases extracellular matrix deposition in ocular fibroblast in vitro. PLos One 2017; 12: E0172592.

13. Sun YW, Zhang YY, Ke XJ, Wu XJ, Chen ZF, Chi P. Pirfenidone prevents radiation-induced intestinal fibrosis in rats by inhibiting fibroblast proliferation and differentiation and supressing the TGF- $\beta 1 /$ Smad/CTGF signalling pathway. Eur J Pharmacol 2018; 822; 199-206.

14. Guo J, Yang Z, Jia Q, Bo C, Shao H, Zhang Z. Pirfenidone inhibits epithelial-mesenchymal transition and pulmonary fibrosis in rat silicosis model. Toxicol Lett 2019; 300: 59-66. 
15. He $\mathrm{Y}$, Revel M, Loty B. A quantitative model of post- laminectomy scar formation. Effects of a nonsteroidal anti- inflammatory drug. Spine (Phila Pa 1976) 1995; 20: 557-63.

16. Hinton JL Jr, Warejcka DJ, Mei Y, McLendon RE, Laurencin C, Lucas PA, et al. Inhibition of epidural scar formation after lumbar laminectomy in the rat. Spine 1995; 20: 564-70.

17. Arabacı Tamer S, Yıldırım A, Arabacı Ş, Çiftçi S, Akın S, Sarı E, et al. Treatment with estrogen receptor agonist ER $\beta$ improves torsioninduced oxidative testis injury in rats. Life Sci 2019; 222: 203-11.

18. Kadıoğlu Yaman B, Çevik Ö, Yalman K, Ertaş B, Şen A, Şener G. Myrtus communis subsp. communis improved cognitive functions in ovariectomized diabetic rats. Gene 2020; 744: 144616.

19. Chen F, Zuo Z, Wang K, Zhang C, Gong H, Ye F, et al. Study on salvianolic acid $B$ in the reduction of epidural fibrosis in laminectomy rats. BMC Musculoskelet Disord 2014; 15: 337.

20. Tanriverdi O, Erdogan U, Tanik C, Yilmaz I, Gunaldi O, Adilay $\mathrm{HU}$, et al. Impact of sorafenib on epidural fibrosis: An immunohistochemical study. World J Clin Cases 2018; 6: 249-58.
21. Dai J, Li X, Yan L, Chen H, He J, Wang S, et al. The effect of suramin on inhibiting fibroblast proliferation and preventing epidural fibrosis after laminectomy in rats. J Orthop Surg Res 2016; 11: 108.

22. Liu X, Yang Y, Guo X, Liu L, Wu K, Yu M. The antiangiogenesis effect of pirfenidone in wound healing in vitro. J Ocul Pharmacol Ther 2017; 33: 693-703.

23. Li Z, Liu X, Wang B, Nie Y, Wen J, Wang Q, et al. Pirfenidone suppresses MAPK signalling pathway to reverse epithelialmesenchymal transition and renal fibrosis. Nephrology (Carlton) 2017; 22: 589-97.

24. Sun $Y$, Zhang $Y$, Chi P. Pirfenidone suppresses TGF- $\beta 1$-induced human intestinal fibroblasts activities by regulating proliferation and apoptosis via the inhibition of the Smad and PI3K/AKT signalling pathway. Mol Med Rep 2018; 18: 3907-13.

25. Shi K, Wang F, Xia J, Zuo B, Wang Z, Cao X. Pirfenidone inhibits epidural scar fibroblast proliferation and differentiation by regulating TGF- $\beta 1$-induced Smad-dependent and independent pathways. Am J Transl Res 2019; 11: 1593-604. 